\title{
CREATIVE ATTITUDE OF PEDAGOGY STUDENTS AND ITS RELATIONSHIP WITH METALEARNING COMPETENCE
}

\begin{abstract}
The ability to manage one's own process of learning (metalearning) is necessary and required of nearly any professional. To develop this skill, you need to have the creative attitude, i.e., to be critical and reflective towards yourself as a learner. This applies even more to teachers, who do not only learn how to learn but should also be able to ensure their students proper conditions for learning this skill. On the other hand, as a person who prepares children and adolescents for creative life in the new millennium, a teacher should display a special level of creativity. The aim of the study presented in this article was to identify the relationship between the creative attitude and metalearning competence of first-year pedagogy students. The results of the study show a statistically significant relationship between the creative attitude and metalearning competence level of pedagogy students.
\end{abstract}

Keywords: creativity; metalearning; teachers' competences; creative attitude.

\section{Introduction}

Current transformations in different areas of professional and personal life make a contemporary human develop an attitude oriented at continuous progress. Humans learn continuously (Spitzer, 2012), and the process of learning involves updating broadly understood knowledge and new skills that emerge in each profession. In the 21st century, in the face of ubiquitous changes, the ability to consciously and effectively manage one's learning process is not only useful but indispensable. The need to realize the essence of developing one's creativity and the metalearning ability is especially important for pedagogy students - future tutors and teachers.

The proposal for a new model of training teacher candidates assumes that they will display a reflective attitude to themselves (their own competences) and to educational practice. Currently, a teacher should be "an expert in supporting child

* MA Monika Żak-Skalimowska, the University of Białystok, Poland, Faculty of Educational Sciences; e-mail:m.zak@uwb.edu.pl. 
development", and therefore, the teacher should know how to assist their students in the process of conscious and autonomous (creative) learning process. Another task for teachers is to create an environment conducive to children's constructive learning. In the face of these assumptions, the most important skill is the creative use of interdisciplinary knowledge on child development for designing educational activities. These skills are an expression of metalearning competence and creative competence.

Each day, teachers have many didactic and educational interactions with other people, which require them to display a creative attitude to their work - to their responsibilities, tasks, and first of all, to other humans. In every new situation we should not repeat what we have done before but be open to novelty and create our own way of living. Janina Uszyńska-Jarmoc (2015a) points out that a creative teacher finds it easier to notice other people, recognize and understand their mental states. In the educational process the teacher is the person who can model how to act and think creatively (Lebuda \& Wiśniewska, 2010; Rubacha, 2000; Strykowska, 2015). Good coping skills in various professional situations require teachers to have the ability to behave flexibly, to change the direction of search to find a solution to the problem, to analyze the reality from many perspectives or to modify styles of work. (Cudowska, 2004) Unfortunately, research results show that the level of creativity (as well as knowledge on creativity) among teachers is rather low (Bernacka 2009; Giza, 1999; Karwowski, 2007; Tokarz \& Słabosz, 2001; Żuk, 1986).

\section{Creative attitude: the theoretical perspective}

In this text it was assumed that creativity can be understood as any human activity resulting in certain outcomes that are socially valuable and original, or at least new and valuable for the person who creates them. The assumption that each human is capable of creating is no longer denied; what is more, creative abilities are perceived as necessary in practically every area of human life (Amabile, 1993; Beghetto \& Kaufman, 2007a; Parashar \& Pingle, 2015; Runco, 2016; Runco \& Jaeger, 2012). This is the egalitarian definition of creativity, i.e., everybody can think and act creatively, and creativity can be learnt (Beghetto \& Kaufman, 2007b).

Research results show that creative people display spontaneity, a sense of humor, expressiveness, courage, openness to experience, curiosity, persistence in carrying out different tasks and the ability to act in an innovative and resourceful way (Bernacka, 2004; Csikszentmihalyi, 1996; Nęcka, 1994; 2012; Popek, 2001; Runco, 2015; Sawyer, 2006; Zhang \& Sternberg, 2011). Human personality traits are visible as the person adopts a certain attitude to the world. The creative attitude is defined

1 The proposal for a new model of teacher education: https://www.ncbr.gov.pl/fileadmin/user_ upload/import/tt_content/files/zalacznik_nr_12a_propozycja_nowego_modelu__ksztalcenia_nauczycieli_przedszkoli_i_edukacji_wczesnoszkolnej.pdf 
in psychological literature as a cognitive and characterological quality referring to the tendency, attitude or readiness to transform the physical world, phenomena, and one's own personality. Thus, it is the person's active attitude to the world and life, reflected in the need to learn about, experience and consciously (in terms of the goal, not the process) transform the present reality and themselves (Popek, 1988, p. 27). The person's creative attitude is affected by the mutual influence of two spheres: cognitive and characterological. The emotional and motivational (characterological) sphere is defined as a set of personality traits which enable the person to use their cognitive abilities. The characterological sphere of creative attitude includes conformist or non-conformist behaviors. According to Stanisław Popek (2010), the characterological sphere plays an important role in the creative process, because personality traits such as high self-esteem, openness to experience, tolerance or the ability to express one's opinion are decisive for the execution of creative ideas. The cognitive sphere can be characterized in terms of heuristic or algorithmic behavior. Heuristic behaviors refer, i.a., to the ability of insightful observation, divergent thinking, reflective and autonomous learning or having productive imagination, while algorithmic behaviors are qualities opposite to heuristic ones, oriented at copying and reproducing tasks, working in accordance with a certain pattern or standard (Popek, 2000, p. 24-25). There is no doubt that the quality of the organized educational environment depends on the level of creativity of future pedagogues. For their professional activity teachers need the skills of designing interesting and inspiring educational projects, inventing new methodological solutions, and first of all, perceiving and developing students' abilities.

\section{Metalearning competence}

Developing the skill of effective and conscious management of one's knowledge, using various learning strategies, the ability to organize and monitor one's learning process and acquiring knowledge on learning is broadly defined as a development of the metalearning skill (Biggs, 1985; Jackson, 2004). If one of the tasks of contemporary education is to prepare children to learn autonomously and consciously, the teachers' responsibility is to create the proper environment conducive to learning about one's own learning process. Metalearning can be defined as knowledge about learning or as an awareness development process of the determinants and learning strategies. Metalearning ability refers to a thoughtful acquisition of information about the process of learning, as well as the use of that knowledge when planning, monitoring, controlling and organizing one's learning process (Carneiro, 2007; Meyer \& Shanahan, 2004; Uszyńska-Jarmoc, 2015b).

The basis for developing the metalearning ability is primarily the reflection on one's learning process, as well as the ability to transform or create new personal ways of learning (Meyer \& Shanahan, 2004). The process of development of metalearning ability may go in several directions, from intuitive learning about one's skills to 
organize the learning process, through acquiring scientific information concerning human learning and comparing how other people acquire knowledge (what learning strategies they use), up to creating one's own concept of learning.

The structure of metalearning competence is made up of three components (Uszyńska-Jarmoc, 2015b): metaknowledge, metacognition and metathinking. Metaknowledge refers to the person's awareness of the level of their own knowledge about the learning process, as well as the need and motivation to gain more information about learning. Therefore, it is important to have both declarative knowledge ("know that" - information on how humans learn) and procedural knowledge ("know how" - the awareness of how to effectively use that knowledge in practice). Metacognition is defined as knowledge about the course of one's own cognitive processes occurring in planning, monitoring and organization of one's learning (Flavell, 1979; Mayer, 1998; Puryear, 2015; Winters, 2011). It is conscious thinking about cognitive processes, requiring the person to concentrate on the course of collecting and processing information in the mind. Metacognition (Basset, 2016, p. 24) is the development of critical thinking about the learning process (one's own and others') and the awareness of what this process involves. The third component of the metalearning structure is metathinking, defined as knowledge about one's own thinking: the way of analyzing various situations, being aware of one's thoughts, and the way of formulating conclusions on the basis of one's experiences. As you ponder over your way of thinking, you engage your memory and attention, trying to remember how you interpret events and your thoughts related to those events. (Crittenden, 2007) To sum up, metalearning is the process of conscious and thoughtful acquisition of knowledge (both academic and personal) about one's own learning process, as well as the ability to use that knowledge effectively in planning and organizing learning.

The term "metalearning competence" is understood much more broadly than metalearning ability. In this text the concept of competence is defined as the combination of knowledge, ability, comprehension and desire. Its structure includes the ability to behave properly, the awareness of the need and impact of one's behavior, and responsibility for the effects (Czerepaniak-Walczak, 1994, p. 134, 137). The presented study assumes a broad understanding of the category of competence. It is a structure made of four components: knowledge, skills, attitudes and responsibility. Every person constructs knowledge in an individual way based on their experiences and reflections - knowledge always has a personal character (Brandon \& All, 2010; Bruner, 2010; Commeyras, 1995; Meger, 2012; Mvududu, 2005). The category of competence is understood as the person's characteristic gained thanks to conscious and planned learning, i.e., gaining knowledge, developing skills and attitudes to one's activities, and first of all, taking the responsibility for one's own process of developing the competence (Czerepaniak-Walczak, 1995). Metalearning competence (Uszyńska-Jarmoc, 2015b, p. 148) is the skill of planning, organizing, monitoring and evaluating one's process of learning, its sources, necessary conditions, outcomes 
and determinants, which is internally motivated, self-regulated and consciously and responsibly used by the individual; it is human characteristic based on a natural, innate ability, i.e., the potential ability to learn humans are born with. This characteristic (a set of different qualities) is also individually varied and changes during the person's lifetime, i.e., it is a temporally determined, practically acquired skill, so it should always be approached dynamically.

In this work it was assumed that creating the concept of one's learning process and program can be understood as a creative process. Both the learning process and the creative process always lead to a change (Gajda, Karwowski \& Beghetto, 2017). The effect of learning in the form of new knowledge can be understood as a creative process because it refers to constructing a new way of understanding the world and oneself, which is valuable and important for this particular person (Beghetto, 2016). Research results show that there is a relationship between the way knowledge is categorized in the mind and a non-standard way of solving problems - an unconventional way of classifying information promotes the creative use of that information in the future (Cropley, 1999). Conscious control and management of the course of one's own cognitive process (e.g., ability to make distant connotations, transform information, change the structure of the problem to solve, draw conclusions and overcome habits concerning schematic, stereotypical thinking) promote unconventional problem solving (Mayer, 1998; Kelly \& Donaldson, 2016; Puryear, 2015). As shown by other studies, there are weak positive correlations between creativity and learning outcomes (Gajda, Karwowski \& Beghetto, 2017) and negative correlations between the efficiency of work and dependence on other people (Dumitrua \& Charif, 2016), which may prove we need the sense of autonomy when carrying out our tasks.

\section{Methodology}

\section{Aims}

The main aim of this study was to find out the relationship between the creative attitude and metalearning competence of pedagogy students. The specific aims of the study were to determine the levels of creative attitude and metalearning competence of pedagogy students.

In the study it was assumed that there is a relationship between the creative attitude and metalearning competence of pedagogy students. No specific hypotheses were formulated in the work because the questions have a diagnostic character (Łobocki, 2003; Maszke, 2004). There are many possible relationships between components of creative attitude and metalearning competence. 


\section{Participants}

The sampling was both purposive and random. Out of all the higher education schools in Poland, six were randomly selected from five geographical areas of Poland: the north, south, east, west and centre. The study involved 648 first-year pedagogy students (women $\mathrm{N}=625$, men $\mathrm{N}=23$, age $\mathrm{M}=21, \mathrm{SD}=3.89$ ). The study was carried out at the University of Białystok, University of Warmia and Mazury, University of Warsaw, University of Gdańsk, Jagiellonian University and University of Wrocław. The students who took part in the study represented the following specializations: early education $(\mathrm{N}=3 \mathrm{O} 3)$, social rehabilitation pedagogy $(\mathrm{N}=90)$, socio-cultural animation $(\mathrm{N}=23)$, andragogy $(\mathrm{N}=6)$, special needs pedagogy $(\mathrm{N}=58)$, education and rehabilitation for people with intellectual disabilities $(\mathrm{N}=19)$, childcare and social pedagogy $(\mathrm{N}=86)$, adult education and social marketing $(\mathrm{N}=19)$, counselling and psychological and pedagogical counseling $(\mathrm{N}=23)$, cross-cultural education with social intervention $(\mathrm{N}=2)$, young children education and care $(\mathrm{N}=4)$, therapy and development support $(\mathrm{N}=14)$, and creative arts education $(\mathrm{N}=1)$.

\section{Instruments}

The quantitative strategy of research results analysis was adopted in the study. In order to find out the level of creativity of pedagogy students, the Creative Behaviour Questionnaire KANH - I was used (Popek, 2010), and the level of metalearning competence of the participants was measured with "My system of learning" questionnaire. (Uszyńska-Jarmoc \& Żak-Skalimowska, 2016)

The KANH - I questionnaire (Popek, 2010) includes 6o statements describing different daily life situations. The statements reflect the person's way of thinking and acting in various circumstances. The participants were asked to respond to each statement and decide whether it is true, partially true or false for them. The participant can receive from o to 2 points for each response. The statements point to characterological or cognitive characteristics of the person's creative or imitative attitude. The outcomes are grouped in four scales: K (conformism), $\mathrm{N}$ (non-conformism), A (algorithmic behaviors), and $\mathrm{H}$ (heuristic behaviors). The $\mathrm{K}+$ A scale reflects the imitative attitude, and the $\mathrm{N}+\mathrm{H}$ scale, the creative attitude. Within each scale the respondent can score from o to 30 points. The outcomes of these scales were subject to separate analysis, as well as combined analysis for $\mathrm{N}+\mathrm{H}$ (from o to 60 points for the creative attitude) and $\mathrm{K}+\mathrm{A}$ (from o to 60 points for the imitative attitude).

"My system of learning" questionnaire (Uszyńska-Jarmoc \& Żak-Skalimowska, 2016) initially included 64 statements concerning all the theoretically identified components of metalearning competence. The students could decide whether each statement was true, partially true or false for them. They could receive from o to 2 points for each response (in some cases, the scoring was reversed). As a result of 
factor analysis, three factors (scales) were identified, referring to specific components of metalearning competence, which together constitute $27.928 \%$ results. The first factor, "the ability to organize one's learning process", is made up of 14 statements (1st scale), the second factor, "declarative (academic) knowledge about human learning" contains 8 statements (2nd scale), while the third factor, "attitude to learning", 3 items ( 3 rd scale). As part of the first scale (variable) one could obtain up to 28 points, as part of the second one, 16 points, and as part of the third one, 6 points. Cronbach's alpha statistics was verified for each scale separately: for the first factor, $\alpha=0.844$, for the second one, $\alpha=0.713$ and for the third one, $\alpha=0.502$. These results are satisfactory and point to sufficient reliability of the scales.

Table 1. Matrix of rotated components for three factors (the components of metalearning competence of pedagogy students)

\begin{tabular}{|l|c|c|c|}
\hline $\begin{array}{l}\text { When I set my own goals and plan my } \\
\text { learning, I am realistic about my abilities to } \\
\text { master the subject }\end{array}$ & factors 1 & factors 2 & factors 3 \\
\hline $\begin{array}{l}\text { I am able to balance the time I spend on } \\
\text { learning and free time. }\end{array}$ & 0,651 & & \\
\hline $\begin{array}{l}\text { I know which aspects of the learning process } \\
\text { I am good at, I am aware of my skills and } \\
\text { I take advantage of them }\end{array}$ & 0,634 & & \\
\hline $\begin{array}{l}\text { Before starting to study, I take account of } \\
\text { all the factors that might be distracting and } \\
\text { I eliminate them. }\end{array}$ & 0,630 & & \\
\hline $\begin{array}{l}\text { I am determined and show perseverance in } \\
\text { the learning process. }\end{array}$ & 0,606 & & \\
\hline I understand what and how I am learning. & 0,571 & & \\
\hline $\begin{array}{l}\text { I know in what way I memorize information } \\
\text { most effectively. }\end{array}$ & 0,568 & & \\
\hline $\begin{array}{l}\text { I can control my emotions during learning, } \\
\text { therefore I am able to concentrate on what } \\
\text { I have to learn. }\end{array}$ & 0,522 & & \\
\hline $\begin{array}{l}\text { I know about different learning styles, so } \\
\text { I select them in such a way as to be most } \\
\text { effective for me at a given moment. }\end{array}$ & 0,521 & & \\
\hline $\begin{array}{l}\text { If I have to master a large amount of mate- } \\
\text { rial, I plan my learning process and schedule } \\
\text { it over a number of days. }\end{array}$ & 0,517 & & \\
\hline $\begin{array}{l}\text { In spite of many attempts, I am unable to } \\
\text { describe the best conditions for optimal } \\
\text { learning. }\end{array}$ & 0,493 & & \\
\hline
\end{tabular}




\begin{tabular}{|l|c|c|c|}
\hline & factors 1 & factors 2 & factors 3 \\
\hline $\begin{array}{l}\text { I like difficult challenges in the learning } \\
\text { process and take them on willingly. }\end{array}$ & 0,469 & & \\
\hline $\begin{array}{l}\text { I can accurately assess my level of knowledge } \\
\text { and lack of knowledge. }\end{array}$ & 0,449 & & \\
\hline $\begin{array}{l}\text { I organize my learning process in such a way } \\
\text { as to overcome my weak points or deficits. }\end{array}$ & 0,410 & & \\
\hline $\begin{array}{l}\text { I know that knowledge about how the brain } \\
\text { learns is important in the learning process - } \\
\text { and so I seek out scientific knowledge in this } \\
\text { area. }\end{array}$ & & 0,647 & 0,428 \\
\hline $\begin{array}{l}\text { I have a great deal of knowledge about the } \\
\text { functioning of the human brain. }\end{array}$ & & 0,631 & \\
\hline $\begin{array}{l}\text { When organizing my learning processes } \\
\text { I take into account theoretical (scientific) } \\
\text { knowledge about how the brain learns. }\end{array}$ & 0,431 & 0,547 \\
\hline $\begin{array}{l}\text { The more stimuli or differentiated tasks to } \\
\text { do, the more neuronal connections are for- } \\
\text { med, which make it easier to place the newly } \\
\text { acquired knowledge in the existing cognitive } \\
\text { structures. }\end{array}$ & & 0,453 & \\
\hline $\begin{array}{l}\text { I am aware of the types of intelligence that } \\
\text { I possess to a greater or lesser extent. }\end{array}$ & & & \\
\hline $\begin{array}{l}\text { I rarely look for information about how } \\
\text { the brain learns, although I am aware that } \\
\text { I know little about it. }\end{array}$ & & & \\
\hline $\begin{array}{l}\text { The brain continuously forms new neuronal } \\
\text { connections, leaving memory traces. }\end{array}$ & & & \\
\hline $\begin{array}{l}\text { I take advantage of every opportunity to } \\
\text { enrich my knowledge in the area of learning, } \\
\text { and so I talk about this with my teachers, } \\
\text { professors and friends. }\end{array}$ & 0,407 & \\
\hline $\begin{array}{l}\text { I agree that the person's emotions do not } \\
\text { have an impact on the process of learning } \\
\text { and retrieving the information memorized } \\
\text { before. }\end{array}$ & & & \\
\hline $\begin{array}{l}\text { I think grades are more important for me } \\
\text { than knowledge, so I try to get good grades. }\end{array}$ & & \\
\hline $\begin{array}{l}\text { I don't like the competition for good grades } \\
\text { at university. }\end{array}$ & & & \\
\hline
\end{tabular}

Source: own elaboration.

All the variables concerning the metalearning competence and the creative attitude of pedagogy students were subject to statistical analysis. Then, Pearson's $r$ 
coefficient of correlation between different components of students' metalearning competence and creative attitude were calculated.

\section{Analysis of research results}

The study (Table 2) allows for a conclusion that pedagogy students have a slightly higher level of non-conformism than conformism. It means that they prefer doing various activities independently, courageously, flexibly and spontaneously rather than schematically, stereotypically and dependently. Having analyzed the outcomes obtained in the cognitive sphere, we can conclude that pedagogy students display a higher level of heuristic than algorithmic behaviors. The results mean that the participants have the ability to make observations on their own, solve open problems and think divergently. The analysis of outcomes of the scales shows that pedagogy students have a higher level of creative attitude than imitative attitude, but both levels are not very high.

Table 2. Statistical characteristics of the outcome of measuring the creative attitude and imitative attitude of pedagogy students

\begin{tabular}{|l|c|c|c|c|c|c|c|}
\hline \multicolumn{1}{|c|}{ Categories } & M & Sd & Sk & K & Max. & Min. & D \\
\hline Conformism & 12,21 & 4,29 & 0,24 & $-0,34$ & 25 & 3 & 22 \\
\hline Non-conformism & 18,71 & 3,83 & $-0,01$ & $-0,43$ & 29 & 9 & 20 \\
\hline Algorithmic behaviors & 13,51 & 3,57 & 0,02 & $-0,21$ & 24 & 3 & 21 \\
\hline Heuristic behaviors & 16,87 & 4,06 & 0,15 & $-0,01$ & 28 & 5 & 23 \\
\hline Creative attitude & 35,59 & 6,92 & 0,11 & $-0,21$ & 55 & 15 & 40 \\
\hline Reproductive attitude & 25,72 & 6,86 & 0,09 & $-0,23$ & 49 & 8 & 41 \\
\hline
\end{tabular}

Source: own elaboration

Table 3 presents the levels of different components of metalearning competence. The students could obtain up to 28 points for the first variable, referring to "the ability to organize one's learning process", 16 points for the second variable, "declarative (academic) knowledge about human learning", and 6 points for the third variable, "attitude to one's own learning".

The data included in Table 3 show that the general level of different components of metalearning competence of pedagogy students is quite low. Pedagogy students have a low level of ability to organize their learning process, including the monitoring and control of their own learning, as well as using personal (individual) knowledge about learning in practice. The high value of standard deviation also shows considerable dispersion of the results around the mean value. The analysis of data presented in Table 3 leads to the conclusion that the students have a very low level of theoretical knowledge on human learning. As shown by the outcomes for the third variable, "attitude to one's own learning", the students have internal motivation to 
learn. The participants declare that they mostly learn to gain knowledge, not high academic accomplishments.

Table 3. Statistical characteristics of the level of components of metalearning competence of pedagogy students

\begin{tabular}{|l|c|c|c|c|c|c|c|}
\hline \multicolumn{1}{|c|}{ Variables } & \multicolumn{1}{c|}{ M } & \multicolumn{1}{c|}{ Sd } & Sk & K & Max. & Min. & D \\
\hline $\begin{array}{l}\text { Ability to organize one's } \\
\text { learning process }\end{array}$ & 16,25 & 5,73 & $-0,26$ & $-0,20$ & 28 & 0 & 28 \\
\hline $\begin{array}{l}\text { Knowledge about human } \\
\text { learning }\end{array}$ & 4,19 & 2,81 & 0,48 & $-0,43$ & 12 & 0 & 12 \\
\hline $\begin{array}{l}\text { Attitude to one's own } \\
\text { learning }\end{array}$ & 4,73 & 1,35 & $-1,14$ & 0,96 & 6 & 0 & 6 \\
\hline
\end{tabular}

Source: own elaboration

The data presented in Table 4 show a statistically significant relationship between the students' ability to organize their own learning process and knowledge about human learning $(\mathrm{r}=0.385, \mathrm{p}<0.01)$. It means that pedagogy students' low scores concerning academic knowledge on learning are correlate with low scores in the monitoring of their own learning process. Besides, there is a statistically significant relationship between students' knowledge on human learning and their attitude to their own learning process.

Table 4. Correlations between the components of metalearning competence

\begin{tabular}{|l|c|c|c|}
\hline & 1 & 2 & 3 \\
\hline Ability to organize one's learning process & 1 & $0,385^{* *}$ & $0,125^{\star *}$ \\
\hline Knowledge about human learning & & 1 & 0,052 \\
\hline Attitude to one's own learning & & & 1 \\
\hline
\end{tabular}

Source: own elaboration

The aim of the statistical analysis was to find the answer to the question: Is there a correlation (and if so, what kind of correlation) between the creative attitude and metalearning competence and their respective components? For this purpose, Pearson's $r$ coefficients were calculated for each variable. The data presented in Table 5 shows that there is a statistically significant but moderate correlation between pedagogy students' non-conformism and ability to organize their own learning process. The characterological sphere concerning the participants' creative behavior is related to the cognitive sphere concerning the ability to organize their learning process $(\mathrm{r}=0.403 ; \mathrm{p}<0.01)$. There is a statistically significant moderate correlation between heuristic behavior and the ability to organize one's learning process $(\mathrm{r}=0.332 ; \mathrm{p}<0.01)$. It means that high scores in creative imagination, ability 
to think divergently and learn autonomously, high reflectivity or verbal creativity are related to high scores in the ability to plan, monitor and control one's learning process.

Table 5. Relationship between the components of creative attitude and components of metalearning competence of pedagogy students

\begin{tabular}{|l|c|c|c|c|c|}
\hline & 1 & 2 & 3 & 4 & 5 \\
\hline Non-conformism & 1 & $0,537^{* *}$ & $0,403^{* *}$ & $0,243^{* *}$ & 0,041 \\
\hline Heuristic behaviors & & 1 & $0,332^{* *}$ & $0,341^{* *}$ & 0,038 \\
\hline $\begin{array}{l}\text { Ability to organize one's learning } \\
\text { process }\end{array}$ & & & 1 & $0,385^{* *}$ & $0,125^{* *}$ \\
\hline Knowledge about human learning & & & & 1 & 0,052 \\
\hline Attitude to one's own learning & & & & & 1 \\
\hline
\end{tabular}

Source: own elaboration

As shown by research results included in Table 6, there is a positive moderate correlation between the creative attitude and the level of metalearning competence of pedagogy students $(\mathrm{r}=0.449, \mathrm{p}<0.01)$. The existing relationship confirms the theoretical assumptions of the research, i.e., the development of metalearning competence is also a creative process. Everyone can create and execute the concepts of their own development (and thus, their personal concept/programs of learning) in an individual, original and valuable way. The study proves that there are relationships between pedagogy students' creative behavior (characterized by a specific way of observation, divergent thinking ability, reflectivity, cognitive activity, independence, responsibility, courage, spontaneity and persistence) and metalearning competence.

Table 6. Relationship between creative attitude and metalearning competence in pedagogy students: summary

\begin{tabular}{|l|c|c|}
\hline & 1 & 2 \\
\hline Creative behaviors & 1 & $0,449^{* *}$ \\
\hline Metalearning competence & & 1 \\
\hline
\end{tabular}

Source: own elaboration

\section{Conclusion}

The conducted research showed that there is a correlation between the general level of students' metalearning competence and their creative attitude. It means that the broadly understood ability to organize and plan their own learning process is related to the process of developing students' creativity. These findings point to the need 
to include both creativity and metalearning contents in higher schools' curricula. As emphasized at the beginning of this article, "creative" means new, original and valuable, at least for the creator. Creativity of a pedagogy student - a future teacher - can manifest itself in creating a variety of new material and symbolic forms which have some value (Kozielecki, 1996, pp. 13-14). Their own learning program, created in an original and unique way, can be such a symbolic and material form. By exploring theoretical issues concerning the pedagogy of creativity and psychology of learning, a pedagogy student can reflectively and consciously create the concept of their own development, and thus, also develop their personality as regards the learning process: endurance, resourcefulness, unconventional thinking, ability to overcome their weaknesses, planning and organizing their work system, and motivation to raise their qualifications.

Statistical analysis showed that there is a statistically significant correlation between the level of academic knowledge (knowing theoretical issues) about human learning and the ability to organize one's own learning process. First year pedagogy students have a low level of knowledge about human learning and an average level of ability to organize their learning process. The results of this research show that the students should study issues connected with the broadly understood phenomenon of human learning even during the first year of their university course. The new model of education for teacher candidates, based on a five-year master's course, can be a good opportunity to acquire reliable, comprehensive knowledge about human creativity and metalearning, and to use that knowledge when designing educational measures. Discovering scientific information on this topic can help the students plan their own learning, and hence, facilitate the optimum organization of the process of self-improvement and professional training in their future jobs. Furthermore, metalearning competence is necessary in their future work as teachers or tutors, whose task will be to help students understand their learning process. The future teacher with no fundamental metalearning knowledge and skills will prepare professionally their students to function in the changeable school and non-school environment. The research results also show that the students have a high level of internal motivation in the process of gaining learning competence, which is a good foundation for further exploration of knowledge, development of creative thinking skills and improvement of the process of self-regulated learning during the university course.

The students who participated in the study have an average level of creative attitude and a low level of metalearning competence. Therefore, it seems necessary to include issues related to the development of students' creative attitude and metalearning competence in curricula from the first year of university education. Discovery of the importance of creativity in daily life and professional activity, as well as the importance of metalearning, may contribute to more conscious and reflective management of students' own learning process during the subsequent years of study (Sternberg, Reznitskaya \& Jarvina, 2007). 


\section{References}

Amabile, T.M. (1993). What does theory of creativity require? Psychological Inquiry, 4(2), 179-237.

Basset, M.H. (2016). Teaching Critical Thinking without (Much) Writing: Multiple-Choice and Metacognition. Teaching Theology \& Religion, 19(1), 20-40.

Beghetto, R.A. (2016). Creative learning: A fresh look. Journal of Cognitive Education and Psychology, 15(2), 1-18.

Beghetto, R.A., \& Kaufman, J. C. (2007a). The genesis of creative greatness: mini-c and the expert performance approach. High Ability Studies, 18(1), 59-61.

Beghetto, R.A., \& Kaufman, J. C. (2007b). Toward a broader conception of creativity: a case form'mini-c' creativity. Psychology of Aesthetics, Creativity, and the Arts, 1(3), 73-79.

Bernacka, R.E. (2004). Konformizm i nonkonformizm a twórczość. Lublin: Wydawnictwo Uniwersytetu Marii Curie-Skłodowskiej.

Bernacka, R.E. (2009). Z badań nad postawą twórczą nauczycieli. In S. Popek, A. Winiarz (Eds.), Nauczyciel. Zawód - powołanie - pasja. Lublin: Wydawnictwo Uniwersytetu Marii Curie-Skłodowskiej.

Biggs, J.B. (1985). The role of metalearning in study processes. British Journal of Educational Psychology, 55(2), 185-212.

Brandon, A.F., \& All, A. C. (2010). Constructivism Theory Analysis and Application to Curricula. Nursing Education Perspectives", 31(2), 89-92.

Bruner, J. (2010). Kultura edukacji. Kraków: Towarzystwo Autorów i Wydawców Prac Naukowych UNIWERSITAS.

Carneiro, R. (2007). The Big Picture: understanding learning and meta-learning challenges. European Journal of Education, 42(2), 151-172.

Commeyras, M. (1995). What can we learn from students' questions? Theory Into Practice, 34(2), 101-106.

Crittenden, V. (2007). Building Skills in Thinking: Toward a Pedagogy in Metathinking. Journal of Education for Business, (September/October), 37-43.

Cropley, A.J. (1999). Creativity and cognition: Producing effective novelty. Roeper Review, 21(2), 253-260.

Csikszentmihalyi, M. (1996). The new frontiers of happines. The creative personality. Psychology Today, (July/August), 36-40.

Cudowska, A. (2004). Kształtowanie twórczych orientacji życiowych w procesie edukacji. Białystok: Wydawnictwo Uniwersyteckie Trans Humana.

Czerepaniak-Walczak, M. (1994). Między dostosowaniem a zmianą. Elementy emancypacyjnej teorii edukacji. Szczecin: Wydawnictwo Naukowe Uniwersytetu Szczecińskiego.

Czerepaniak-Walczak, M. (1995). Refleksja zawodowa nauczyciela-wychowawcy, jej przedmiot, źródła i rola. In H. Kwiatkowska, T. Lewowicki (Eds.), Z zagadnień 
pedeutologii i kształcenia nauczycieli. Komitet Nauk Pedagogicznych Polskiej Akademii Nauk.

Dumitrua, D., \& Chraif, M. (2016). The Relationship Between Personality Traits, Cognition And Performance Motivation. Romanian Journal Of Experimental Applied Psychology, 7(1), 383-386.

Flavell, J. H. (1979). Metacognition and Cognitive Monitoring A New Area of Cognitive - Developmental Inquiry. American Psychologist, 34(1), 906-911.

Gajda, A., Karwowski, M., \& Beghetto, R. A. (2017). Creativity and Academic Achievement: A Meta-Analysis. Journal of Educational Psychology, 109(2), 1-31.

Giza, T. (1999). Przygotowanie studentów do twórczej pracy pedagogicznej. Kielce: Wydawnictwo Wyższej Szkoły Pedagogicznej im. Jana Kochanowskiego.

Jackson, N. (2003). Developing the concept of metalearning. Innovations in Education and Teaching International, 41(4), 391-403.

Karwowski, M. (2007). Teachers' Nominations of Students' Creativity: Should We Believe Them? Are the Nominations Valid? The Social Sciences, 2(3), 264-269.

Kelly, D., \& Donaldson, D.I. (2016). Investigating the complexities of academic success: Personality constrains the effects of metacognition. The Psychology of Education Review, 40(2), 17-23.

Kozielecki, J. (1996). Człowiek wielowymiarowy. Warszawa: Wydawnictwo Akademickie „Żak”.

Lebuda, I., \& Wiśniewska, E. (2010). „Stwarzanie samego siebie” - jakościowe studium sukcesów i planów życiowych młodych pedagogów. In M. Karwowski, A. Gajda (Eds.), Kreatywność (nie tylko) w klasie szkolnej. Warszawa: Wydawnictwo Akademii Pedagogiki Specjalnej.

Łobocki, M. (2003). Metody i techniki badań pedagogicznych. Kraków: Oficyna Wydawnicza „Impuls”.

Maszke, A. W. (2004). Metodologiczne podstawy badań pedagogicznych. Rzeszów: Wydawnictwo Uniwersytetu Rzeszowskiego.

Mayer, R.E. (1998). Cognitive, metacognitive, and motivational aspects of problem Solving. Instructional Science, 26(2), 49-63.

Meger, Z. (2012). Od behawioryzmu do konektywizmu współczesnego e-learningu. Edu@kcja. Magazyn edukacji elektronicznej, 1(3), 14-26.

Meyer, J.H.F., \& Shanahan, M.P. (2004). Developing metalearning capacity in students: actionable theory and practical lessons learned in first-year economics. Innovations in Education and Teaching International, 41(4), 443-458.

Mvududu, N. (2005). Constructivism in the Statistics Classroom: From Theory to Practice. Teaching Statistics, 27(2), 49-54.

Nęcka, E. (1994). Proces twórczy i jego ograniczenia. Kraków: Oficyna Wydawnicza "Impuls".

Nęcka, E. (2012). Psychologia twórczości. Sopot: Gdańskie Wydawnictwo Psychologiczne. 
Parashar, S., \& Pingle, S. (2015). Creativity: An Assessment of Teachers and Students. University Journal of Research, 1(1), 124-139.

Popek, S. (1988). Zdolności i uzdolnienia twórcze. In S. Popek (Ed.), Aktywność twórcza dzieci i młodzieży. Warszawa: Wydawnictwa Szkolne i Pedagogiczne.

Popek, S. (2001). Człowiek jako jednostka twórcza. Lublin: Wydawnictwo Uniwersytetu Marii Curie-Skłodowskiej.

Popek, S. (2010). Kwestionariusz twórczego zachowania KANH. Lublin: Wydawnictwo Uniwersytetu Marii Curie-Skłodowskiej.

Puryear, J.S. (2015). Metacognition as a Moderator of Creative Ideation and Creative Production. Creativity Research Journal, 27(4), 334-341.

Rubacha, K. (2000). Petnienie roli nauczyciela a realizacja zadań rozwojowych w okresie wczesnej dorosłości. Toruń: Wydawnictwo Uniwersytetu Mikołaja Kopernika w Toruniu.

Runco, M.A. (2015). Meta-Creativity: Being Creative About Creativity. Creativity Research Journal, 27(3), 295-298.

Runco, M.A. (2016). Commentary: overview of developmental perspectives on creativity and the realization of potential. In B. Barbot (Ed.), Perspectives on creativity development. New Directions for Child and Adolescent Development. New York: John Wiley \& Sons.

Runco, M. A., \& Jaeger, G. J. (2012). The standard definition of creativity. Creativity Research Journal, 24(1), 92-96.

Sawyer, R.K. (2006). Explaining creativity: The science of human innovation. New York: Oxford University Press.

Spitzer, M. (2012). Jak uczy się mózg? Warszawa: Wydawnictwo Naukowe PWN.

Sternberg, R.J., Reznitskaya, A., \& Jarvina, L. (2007). Teaching for wisdom: what matters is not just what students know, but how they use it. London Review of Education, 5(2), 143-158.

Strykowska, J. (2015). Kreatywność w życiu zawodowym nauczyciela. In J. Skibska, J. Wojciechowska (Eds.), Nauczyciel i uczeń w przestrzeni kreatywnych działań. Warszawa: Wydawnictwo Akademickie „Żak”.

Tokarz, A., \& Słabosz, A. (2001). Cechy uczniów preferowane przez nauczycieli jako wymiar aktywności twórczej w szkole. Part II. Uczeń idealny i twórczy w preferencjach badanych nauczycieli. Edukacja. Studia. Badania. Innowacje, $3(75), 36-48$.

Uszyńska-Jarmoc J. (2015b). Poziom samooceny kompetencji metauczenia się i jej wymiarów a osiągnięcia szkolne uczniów klas pierwszych liceum. In J. UszyńskaJarmoc, M. Bilewicz (eds.), Kompetencje kluczowe dzieci i młodzieży. Teoria i badania. Warszawa: Wydawnictwo Akademickie Żak.

Uszyńska-Jarmoc, J. (2015a). Kreatywność nauczycieli a ich przekonania i intencje dotyczące interakcji wychowawczych z dziećmi. In J. Uszyńska-Jarmoc, B. Kunat (Eds.), Twórczość codzienna jako aktywność całożyciowa człowieka. Białystok: Wydawnictwo Trans Humana. 
Uszyńska-Jarmoc, J., \& Żak-Skalimowska, M. (2016). Kwestionariusz „Mój system uczenia się" (unpublished work).

Winters, T. (2011). Facilitating Meta-learning in Art and Design Education. International Journal of Art \& Design Education, 20(1), 90-101.

Zhang, L., \& Sternberg, R. J. (2011). Revisiting the Investment Theory of Creativity. Creativity Research Journal, 23(3), 229-238.

Żuk, T. (1986). Uzdolnienie twórcze a osobowość. Poznań: Wydawnictwo Naukowe UAM.

\section{POSTAWA TWÓRCZA STUDENTÓW PEDAGOGIKI I JEJ ZWIĄZEK Z KOMPETENCJĄ METAUCZENIA SIE}

Streszczenie: Umiejętność zarządzania własnym procesem uczenia się (metauczenie się) jest niezbędną i oczekiwaną cechą człowieka wykonującego niemal każdy zawód. Rozwijanie tej umiejętności wymaga postawy twórczej - krytycznej i refleksyjnej wobec siebie - jako osoby uczącej się. Dotyczy to tym bardziej zawodu pedagoga, który nie tylko sam uczy się, jak się uczyć, ale także powinien umieć stwarzać warunki uczniom do zdobywania tej umiejętności. $\mathrm{Z}$ drugiej strony nauczyciel jako osoba przygotowująca dzieci oraz młodzież do twórczego życia w nowym tysiącleciu, powinien w szczególny sposób wykazywać się kreatywnością. Celem badań przedstawionych w niniejszym artykule było określenie związku między postawą twórczą, a kompetencją metauczenia się studentów pedagogiki. Wyniki przeprowadzonych badań wskazują, że istnieje istotny statystycznie związek między postawą twórczą i kompetencją metauczenia się studentów pedagogiki.

Słowa kluczowe: kreatywność; metauczenie się; kompetencje nauczycieli; postawa twórcza. 